\title{
Learning to Reflect in Online Fantasy Role-Playing Games ${ }^{*}$
}

\section{Çevrim-içi Fantazi Oyunlarında Yansımayı (Tefekkürü) Öğrenme}

\author{
Tunç D. MEDENi", Kazunori MiYATA***, Mustafa SAĞSAN****
}

\begin{abstract}
The online role-playing games and their virtual communities, which are free and run by volunteers, attract much attention from business and academics, although studies on smaller gaming communities are still limited. One of these small online fantasy roleplaying communities, the world of Wold, is researched, using participant observation and Internet interviewing techniques within an e-research framework. After providing background information about the research, the paper then presents the conceptual framework, which consists of three main parts: (1) use of asynchronous communication tools for learning and reflection, (2) conceptualization of reflection, and (3) role of roleplaying and storytelling in reflection and learning. In the light of this framework, research findings about the learning and reflection that occurs at (1) intrapersonal, (2) personal and (3) interpersonal levels in online role-playing games will be discussed. The paper will then be concluded by research implications and limitations. It is hoped that, relating to learning in terms of developing sustainable virtual communities for reflective learning, this research will provide insights into the function of multiplayer games for serious purposes like learning and socialization, as well as the role of hard technology for soft purposes like reflective learning and practice.
\end{abstract}

Keywords: Knowledge sharing, Knowledge creation, Role-playing, Reflection, Communities of practice

\section{Öz}

Gönüllüler tarafından oynanan ve ücretsiz olan çevrim içi rol oyunları ve sanal toplulukları, daha küçük oyun topluluklarıyla ilgili çalışmalar sınırlı sayıda olmasına rağmen, iş ve akademi çevresinde daha fazla cezbedici hale gelmiştir. Bu çalışmada

\footnotetext{
* Bu çalışma, Medeni, Elwel, Cook ve Souza adlı yazarlar tarafından kaleme alınan "Learning Reflection and Creativity in Online Game Communities" adlı çalışmanın genişletilmiş halidir.

** Dr.; TURKSAT, Cevizlidere Cad. No:31, Ankara. (tdmedeni@turksat.com.tr)

*** Prof. Dr.; Japan Advanced Institute of Science and Technology (JAIST), Asahidai, Nomi, Ishikawa, Japan 923-1211. (miyata@jaist.ac.jp)

**** Dr.; Başkent Üniversitesi Bilgi ve Belge Yönetimi Bölümü, Bağlıca Kampusu, Ankara. (msagsan@ baskent.edu.tr)
} 
bu küçük çevrim içi fantezi rol oyunları topluluklarından birisi olan Wold'un Dünyası ele alınmış ve katılımcılarla ilgili olarak Internet görüşmeleri tekniği kullanılmıştır. Araştırmanın arka planıyla ilgili enformasyon verildikten sonra, araştırmanın üç kısımdan oluşan çerçevesi sunulmuştur. Bunlar, 1) öğrenme ve tefekkür için eşzamansız iletişim araçlarının kullanılması 2) tefekkürün kavramsallaştırılması 3) tefekkür ve öğrenmede hikâye anlatımı ve rol oyunlarının rolüdür. Bu çerçeve ışığında, 1) kişinin kendisi ile 2) bireysel olarak ve 3) kişiler arsında oluşan tefekkür ve öğrenmeye ilişkin bulgular, çevrimiçi rol oyunlarında tartışılmıştır. Çalışma, yapılan araştırmanın uygulanabilirliği ve sınırıııklarıyla bir sonuca varmıştır. Umulmaktadır ki, bu olgudaki gelişme, öğrenmeyle ilgili tefekkürün oluşabilmesine yönelik gelişmekte olan sürdürülebilir sanal toplulukların çok oyunculu bir yönde değişim göstermesini ve katı teknolojiden daha hafif tefekküre yönelik öğrenme ve uygulamalara doğru bir amaca yönelimin gerçekleşmesini sağlayacaktır.

Anahtar sözcükler: Bilgi paylaşımı, Bilgi üretimi, Rol oyunları, Yansıma (tefekkür), Uygulama toplulukları

\section{Introduction}

The increasing popularity of online role-playing games and the virtual communities they create are attracting much attention from business and academics. These virtual communities and environments provide invaluable opportunities for researchers to investigate various social and psychological aspects and issues, such as the role that online fantasy role-playing games and gaming communities can play for the learning of their playing members, or the virtual practice and learning of reflection in the game for real life and learning.

The studies on fantasy role-playing games have a longer history than the investigations about the link between learning and role-playing games. Lortz (1979, p.36) defines fantasy role-playing game as a game, which allows a number of players to assume the roles of imaginary characters and operate with some degree of freedom in an imaginary environment. Gaming fantasy combines the expressive freedom of fantasy with the structure characteristics of games. Fantasy role-playing gamers, the party of players and game masters create their own cultural systems, generating identities and meanings in complex social worlds (Fine, 2002). With the development of information and communication technology (ICT) these games are carried to online environments.

Online role-playing games have developed entire virtual worlds and communities with a sense of purpose, a shared history, and complex social interactions (Powazek, 2001; Murray, 2004). While the primary purpose of these (online) gaming communities is to have fun, nestled within them are important social and psychological phenomena such as identity construction, storytelling, learning, leadership, cooperation and competition. Moreover, phenomena emerging in these online communities can also be investigated almost entirely by unconventional online research methods such as Internet Interviewing (e-Interviews), systematically following an e-Research methodology. As Anderson and Kanuka (2003, p. 1) points out the e-research makes use of the Internet 
as a cost-effective communication medium as well as a challenging and reshaping context to globally interact and inquire, providing a new focus and "frame through which to study the world and the creatures that live in it." Data collection and analysis, dissemination of findings and outcomes on Internet raises important issues related with ethics, authenticity, and copyrights that could be most-successfully addressed with such e-research focus and frame.

Within the field of educational research there is a wide-spreading interest in online communities and virtual worlds: Online technologies provide new opportunities for 'anytime/anywhere' social interaction, and the number of innovative curricular designs that incorporate online collaborative environments has been steadily increasing since such technology first emerged. As Lave and Wenger (1991) argue, understanding learning in naturally occurring contexts, and not just within formal ones, is crucial, if we are to forward learning and educational theory and practice beyond the contexts we ourselves contrive. "We ought to investigate more naturally occurring, self-sustaining indigenous virtual cultures so that our theory might be a more accurate reflection of them and our practice a better reflection on them in days to come" (Steinkuehler, 2005, pp. 80-1, Galarneau, 2004).

Along with the increasing interest in online communities and virtual worlds, the use of asynchronous computer-mediated communications to support educational practices are also growing. Asynchronous communication methods in general deserve special attention, since this method is specifically regarded as being open to discussion, thus promoting the development of understanding, even through disagreements (Joinson, 2003). In addition, asynchronous communication is highlighted for its contribution to personal and collective reflection for learning, which will be elaborated for the further sections.

Following a similar line of purpose and perspective, we have conducted research in the online Woldian games. The fantasy world of Wold, which began as a homemade local campaign in 1985 in U.S.A., has now become an online community with around 100 active members, who asynchronously interact with each other by posting on various boards for gaming and chatting within the community website, www.woldiangames. com. By paying the utmost attention to maintaining its free and volunteer nature and blending veteran players with new recruits, the Woldian world has achieved a lot as a community. For instance, when the life companion of one member passed away, an hour of silence was conducted on the players' chatting board to show their grief. The name of another member, who passed away at a young age, was given to a discussion board to keep her memory alive, as well. Woldian world has also made good use of its online digital environment by archiving all the games and chats, and providing virtual facilities for learning, research and development. For instance, the Rules Center functions as a place for discussion and questions about the application and interpretation of the game rules, and the Black Genie Center helps Woldians research what they would like to create for their characters and others to use in the games. 
As a collective story writing and role-playing space Wold provides valuable opportunities for reflection and learning. Choices made for the development of character concept include the intentions to reflect and experience aspects of real life. The exploration and development of interpersonal relations become possible during game events. Playing members can practice and improve certain social skills for specific tasks. Players take time to imagine and spell out the actions of characters they role-play, receiving feedback and reaction from other characters, and game masters. This experience of social interaction brings its own rewards and frustrations, resulting with good and bad examples of relationship, planning, leadership, and collaboration. In one case, for instance, players threatened to leave the game, having developed hard feelings about the leader's role in the game. These interactions include aspects not only 'in-character' but also 'out-of-character', as fantasy role-playing is also a part of what members routinely do in their real daily life.

As an active participant in the online community for almost two years, valuable data and information have been collected by contributing to the playing and other community activities. Furthermore we have been conducting email interviews with other players, with whom we have relatively close communication and whom we have thought would have insightful comments and be available for the purposes of our research. As a complementing aspect of such e-research methodology, which is introduced above, literature review has also extensively relied on online sources in our research. Together with this research, we have continued to develop our theoretical framework and formulated a three-level reflective learning and practice schema for further investigation.

Intrapersonal reflection and learning: Projective and reflective mirroring between the players and game character created by player for learning more about one's self by experiment and discovery within the gaming groups

Personal reflection and learning: Reflective thinking and internalizing knowledge about a specific topic acquired by experience in real offline life, or virtual online play

Interpersonal reflection and learning: Learning transferable skills as well as externalizing and developing knowledge through reflective interactions with other players in games or other online activities like discussing about the game rules or item developments

We have asked questions about these distinguished types of reflection and learning to our interviewees and received various responses in support of our own conceptualization and experience. While the responses to our interviews have been fulfilling for the purposes of conducting a good quality qualitative research, the sample size is small, which mainly reflects the small size of the Woldian gaming community. There are a number of games that operate at such a small size that are less often studied compared to other larger games, which are free and run by volunteers, such as the earlier Multi-User Dungeon (MUDs) and Object oriented MUDs. Thus, we hope our research aids in filling a gap in current research related to development and functioning 
of sustainable learning communities, especially with the rise of serious games and games for health (games for self-esteem and games for relaxation). Meanwhile, the research is aimed to exhibit an interesting account of how hard digital technology could be used for soft purposes like personal and interpersonal reflection, which could stimulate further interest in the use of digital technology for reflective learning and practice.

Serious Games, nevertheless, have been widely developed to build better link between digital games and education. As important characteristics of such games, Shih and Su (2008) identify common characteristic defined by scholars: (1) Goals and tasks, (2) Challenge, (3) Authenticity, (5) Exploration, (6) Interactivity, (7) Feedback, (8) Competition and cooperation, (9) Learning after action, (10) Story-telling. Both theoretical and practical needs, as well as the potentiality of extending current games' value are important for the design and delivery of such games. The games should not sacrifice their entertaining value to enhance the games' educational value, making the form of game too serious.

In the next section, we will provide more detailed background information about our conceptual framework. The following section will then discuss more about our research findings with the presentation of the collected data.

\section{Reflection and Learning through Asynchronous Communication Tools in Fantasy Role-playing}

In this section we will present the framework that we rely on in the discussion of our findings and ideas. The framework has three main aspects: first is the use of asynchronous communication tools for learning and reflection, second is the conceptualization of reflection, and third is the role of role-playing and storytelling in reflection and learning. We will discuss each aspect one by one as the following.

\section{Asynchronous communication tools for learning and reflection}

Asynchronous communication tools like 'listservs, email, discussion forums' have contributed to transforming how people communicate and share knowledge, or learn and reflect. A discussion thread is a good example of reflective learning from an asynchronous tool: "One learner can post a thought, and hours (or days) later, another learner can comment on the posting. Learners can engage each other when it is most convenient...and, a knowledge trail is left of discussion posts, which helps the ones that are trailing behind. Content of the messages can be explored and discussed in great depth - allowing learner's time to reflect and formulate thoughtful responses." (eLearnspace, accessed 13.07.2006) Comments in a discussion board (Techsoup, 2005) for asynchronous communication are supportive of this argument, as well:

....asynchronous communication allows for more 'thoughtful' discussions. The learners and tutor can spend time crafting their remarks so the discussion may be more organized 
and thorough. You can arrange your thoughts better, get your ideas and points set before posting...you are more likely to say what you mean if you have time to compose. There is... opportunity to think before 'speaking', a much higher level of reflective thinking and deep conversation than in face-to-face or chat environments...

However, there are important disadvantages related with this type of communication. First it is "very hard to initiate dialog" (Techsoap, 2005). One reason could be that in face-to-face situations "silence is an enemy, and someone will always pipe up rather than tolerate the silence" (Techsoap, 2005). On the other side, "cyberspace is a vacuum. Questions or comments can sit out there, cold and lonely, unless there's incentive for others to respond". (Ibid) What is more, "sometimes it can be difficult to sustain a meaningful dialogue when there is not necessarily an expectation of a response by one or more of the parties involved" (Techsoap, 2005). In a real-time conversation, one can "dedicate the attention needed to discuss whatever the situation warrants; however," for instance, in web forums "it can be annoying when you spend a good bit of time making a contribution to a discussion, then to have days go by with not so much as a hint of a reply from others" (Techsoap, 2005).

There are also suggestions to deal with these problems. First of all, learners need to be encouraged and nurtured. Regular reminders to non-posters, or lurkers can prove to be helpful. Then, finding "someone who can spend 1-2 hours a week in the discussion, linking ideas together, responding to posts, and asking questions of people reading (many people will move from reading to responding if you ask them to)" could be useful, as well. "This can be a great role for a virtual volunteer. Come up with a catchy title for the role and select a volunteer carefully" (Techsoap, 2005).

On the web, Goldberg (2006) summarizes the benefit of asynchronous communication in comparison to synchronous communication as follows: While synchronous communication tools remove the geographical barriers, asynchronous communication tools remove both the geographical and temporal barriers. "Aside from making the communication that much more accessible, removal of the temporal barrier also has a side effect. People all of a sudden have time to consider the discussion they are part of a little more carefully. They have time to weigh the issues and form their argument or contribution. They can do some research to support their argument. They have time to proofread and spell check. All this tends to elevate the quality of the discussion" (Goldberg, accessed 13.07.2006). Flexibility of time that comes with asynchronous communication fosters "deeper" processing of information and opportunities for not only personal but interpersonal reflection, as well. This type of reflection would not be possible with the use of synchronous communication, although it should also be acknowledged that the nature of real-time interaction may allow for reflective thinking of a more spontaneous kind.

The use of asynchronous computer-mediated communication tools to support educational practices is also growing in particular to support and promote computersupported collaborative learning. There are a number of benefits from collaboration for learning, as Steeples (1998), from the Centre for Studies in Advanced Learning 
Technology at Lancaster University, UK discusses them. First of all, group members can collaborate to learn, which necessitates them in articulating and explaining their ideas to each other. "Articulation 'externalizes' ideas for scrutiny by the group member him/herself, as well as by the other members of the group. Explaining one's ideas and sharing perspectives and viewpoints encourages each group member to examine their own ideas in the light of others' views. "' (Steeples, 1998, accessed 15.09.2005) Second, as group members learn to collaborate, the experience teaches them important skills, which include "personal transferable skills eg. communication, coordination, selfmanagement" (1998 and 2005). Collaboration using technology in the learning process itself is important and attractive for learners to take to the workplace. Steeples (1998 and 2005) also discusses that collaborative interactions trigger cognitive mechanisms that:

include conflict or disagreement, where diverging viewpoints lead to verbal interactions. Quite close to conflict is the alternative proposal, which is said to reduce confirmation bias. (Self-) explanation refers especially to the benefits of giving elaborated explanations for oneself, as well as for others. Internalization draws upon Vygotsky's socio-cultural theory, and refers to the notion of integrating new knowledge into one's own reasoning. Other mechanisms include appropriation whereby a learner reinterprets the action of others into his/her own plan... Mutual regulation or the justifying of one's actions to others is seen as beneficial, including improving self-regulation skills. Not least, social grounding concerns ensuring that the other group members understand what you meant, as well as building together a common base of shared understanding.

Most computer-supported collaborative learning tools use shared external representations (Bodemer and Sholvien, 2008). While learning with multiple representations is demanding even in individual learning settings, (task-based) computer-supported collaborative learning situations that combine the demands of multimedia learning and (distributed) net-based knowledge communication highly increases complexity. During such knowledge communication, for instance, learners can encounter difficulties, such as (1) establishing references between external content and collaboration content, (2) constructing a mutual understanding and a common ground and - associated therewith - constructing a representation of the learning partner's knowledge or beliefs, as well as (3) interacting with each other in a structured and goal-oriented way. Thus, while most of the existing studies focus on learning with animations or simulations, there is only little research on learning with complex multimedia learning material (Bodemer and Sholvien, 2008).

The concepts of internalization and externalization that are facilitated by asynchronous communication tools can also be associated with Nonaka and Takeuchi's (1995) knowledge-creation theory that is based upon knowledge conversions between tacit and explicit knowledge(s) at different individual and collective levels. Externalization is the conversion from tacit knowledge to explicit knowledge with the support of metaphors, analogies and models, whereas internalization is the conversion of explicit knowledge into tacit knowledge mostly through learning by doing. We understand reflection as a two-way process that can be used for both externalizing 
and internalizing knowledge, which can be explained by a (personal and interpersonal) knowledge-creation perspective. One can reflect on some issue by deliberately thinking on it mostly as a result of experience, as well as by expressing one's comments as a result of what one has thought. Through interaction with other pieces of information in mind, or with other people and artifacts in the environment outside, an individual can get involved in the construction of personal and collective knowledge.

Knowledge creation is generated through the synthesizing interplay between dialectics, tacit<>explicit, individual<>social, action<>cognition (Nonaka and Teece, 2001), or the various differences among the ideas of the members of a group. Reflection interlinks the dialectical entities to construct a shared understanding. Thus, interactions and discussions with our own selves and others are significant for reflection and learning. Disagreements and confrontations within our selves or within informal, collaborative online settings can be useful for reflection and development. For the latter, for instance, Aakhus (2001) discusses the design and use of a webbased application, 'virtual dialectic', created to facilitate learning from experience. The virtual dialectic application addresses how people make sense of communication, help individuals develop their self-understanding and identity, and explores, essentially, how to articulate cooperation at conflict through a reflective dialogue. Alterity, disagreement, and conflict are important collaborative achievements that contribute to learning, decision-making, and innovation processes.

\section{Reflection}

Our discussion has led to a point that there is need to make explicit how we understand and conceptualize reflection. We can define (the art of) reflection as (the act of) contemplating and articulating past experience and future purpose for present practice that is perceived within a context shaping and shaped by individual actions. We should try to reflect on what (including how, why etc.) we are doing at present with respect to our relationships with others, with a perspective on both the past and the future (Schön, 1983, Weick, 1995, Medeni, 2001, 2004). Reflection is a significant concept for acting, and knowing, or making sense of, learning about, creating, and transferring knowledge. This vast range of conceptualizations also makes different interpretations and derivations of the concept possible. The comprehension of reflection can come from sources as varied as psychoanalysis, physics, religion and social movement theories, as well as from different levels, from intra-individual to inter-social, however here we focus only on intra-to-inter-personal levels (Medeni, 2006). 


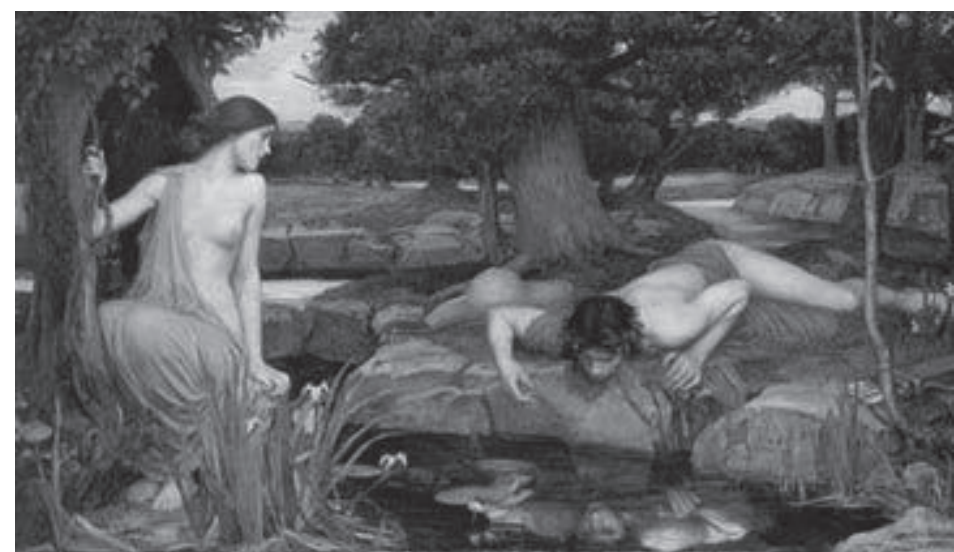

Figure 1. Echo and Narcissus

Source:(http://www.liverpoolmuseums.org.uk/walker/collections/20c/Waterhouse.asp)

For instance, looking at Figure 1, we can provide an easy explanation about the physical reflection, which we commonly come across in our daily lives, such as the image of the young man on the surface of the water. However, there is more to this, if we recognize this picture as "Echo and Narcissus" painted by Waterhouse (1903). While a mirror image is a reflection we perceive with our eyes, an echo is a reflection we perceive with our ears. Furthermore, according to the myth Narcissus falls in love with himself, his own reflection on the water.

Finding their roots in such mythological stories or other works of the classical age, psychology and psychoanalysis make use of reflection as well, such as in the works of Lacan (1977), or in transactional analysis. Similar links between the natural world and the social world provide rich sources of metaphorical relations to explain and use the concept of reflection, such as in the cartoon, "Future and past are relative," by Alizadeh. With regard to this, one of the important aspects of the concept of reflection is that it is not limited to past experience. Together with the past one can reflect on future, for instance about one's purposes or plans to reach these purposes. By reflecting upon the past, and upon the future, then present experience can be "unfolded", with respect to the original meaning of the word, "re-flect" (Medeni, 2006).

There are various ways to reflect on our own selves so that we can manage the self-knowledge that is constructed either in relation to or in various types of relationship with others. For instance, to use a physical metaphor, consider a person inside a room looking out from the glass window at twilight. As it gradually gets dark the window glass turns into a mirror, reflecting the person together with the surroundings. In daily life, keeping a diary or a relaxing shower can all contribute to such personal reflection. Furthermore, it is also important to consider reflection as a collective act 
that includes other people. This inclusion of others can be at different levels such as considering self-knowledge in relation with others, or assuming social responsibility for contributing to the reflective act of others and learning from their reflections. In the same sense, we can also reflect on ourselves using another person as a reflective mirror. In the story of Echo and Narcissus, Echo, who falls in love with Narcissus does not hesitate to assume the role of the reflected image of the man she loves and echoes back what Narcissus tells his beloved image in order to win his heart. The same logic applies using another context as a mirror to reflect upon our own context, as when, for instance, we visit a different place or the same place at different times. Reflective debriefing discussions (such as "After Action Reviews" see Collison, and Parcell, 2004) or managerial exchange programs (such as the Management Exchange in the International Masters program in Practicing Managers, Mintzberg, 2004) can be used for this collective reflection, when, using other persons as mirrors, participants can get the chance to reflect on themselves and others (Medeni, 2006).

\section{Storytelling and role-playing for reflection and learning}

The use of storytelling and role-playing for education and learning has a long history. An example of this, Yaren (Friend) Talks, still continue in Çankırı, Turkey as a living tradition of the "corporations" of craftsmen and guilds of artisans, the communities of practice of ancient times and the Middle Ages. Yaren Talks assume an important role in the members' life after work. They function as an educational institution, especially for the young boys in the community, while providing recreation for the members, with special events, which includes, among other activities, folk music and dance performances and the serving of special cuisine as well (Figure 3) (Medeni, 2005).

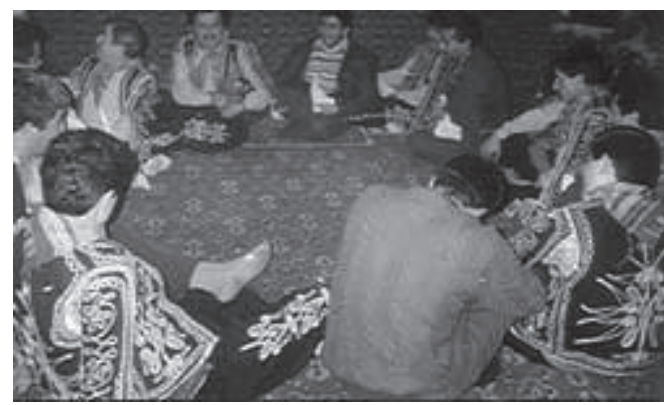

Figure 2. Yaran Talks

(Source: http://www.cankiri.gov.tr/ana/kultur/yaran.htm and http://www.karatekin.net/yaren/)

Writing, telling, and taking part in stories itself could be considered as an important learning tool for reflection, as well. As Barrett $\left(2004 a, 2004 b^{2}\right)$ quotes from Schön (1988) "stories are products of reflection, but we do not usually hold onto them long enough to make them objects of reflection in their own right." Still, through reflection 
we revise our own stories of what has happened and is happening thus resolving anomalies in our thinking and building systematic knowledge (Umphrey, 2005).

Role-playing is like being and playing in an improvisational drama or free-form theatre, in which the participants adopt imaginary characters, or parts, that have personalities, motivations, and backgrounds different from their own. Based upon this, Fantasy Role-Playing Game is a type of game, which allows players to role-play imaginary characters in an imaginary setting. Usually, role-players engage in cooperatively creating a story, each restricting them to the character they themselves introduced to the story. Online Fantasy Role-Playing Game is also a role-playing activity, in which, rather than meeting in real life and using items like pens, pencils, dice etc., players can benefit from ICT tools and interact with each other by using either asynchronous methods like posting on boards or sending emails, or synchronous ones that are evolving from text-based non-graphical into graphical forms, which can be supported by audio, as well (Medeni and Medeni, 2005).

Fantasy role-playing games require participants to enact individual or team roles, often within a science fiction or fantasy scenario. These role-playing activities focus on skills and concepts related to such topics as leadership, teamwork, and planning. As part of an intranet (a password-protected local network), online fantasy role-playing games would allow learners to interact simultaneously with other users and with the environment itself, fulfilling objectives like attaining high levels in game characters and adventures, exploring, making friends and acquiring knowledge and skills (Lee 2000). Filipczak (1997), Griffiths and Davies (2002), and Gee (2003) note that online fantasy role-play games have a potential for offering a variety of experiential learning opportunities. Inherently social, these types of games support both social learning' and'situated learning'. They also support pattern recognition and reasoning on the basis of patterns that players pick up in the real and virtual world. Moreover, they enable exploration of interpersonal relationships. Such games also can encourage cooperative and competitive behavior within a strategic context. Finally, reflective debriefing after the role-play can draw parallels between the fictional fantasy and real life (Mitchell and Savill-Smith 2004, accessed 13.07.2006).

Interactions with other players or characters, successes or failures in the online fantasy role-playing games generate valuable emotions, which are, as Barrett suggests (2004), significant for a deeper learning. These games also incorporate fun as an important element of learning. As Totty (2005, accessed 13.07.2006) claims, "evidence suggests adults learn more and retain more in courses that incorporate such game elements as competitive scoring, increasingly difficult player levels and fantasy role playing." Various studies (Tsikalas, 2001, Lue, accessed 13.07.2006) also highlight the contribution of online fantasy role-playing games to individual and collective learning and reflection. According to these studies, role-playing technologies within digital environments/spaces can facilitate interpersonal dialogue and inquiry for reflective learning, which then contribute to the socio-emotional development of participating players as well as revival of social capital and reaffirmation of affective 
learning. With reflective learning, Tsikalas (2001) documents that verbal fluency, visual intelligence, pattern recognition and rule discovery are gained by players. Meanwhile, Lue (accessed 13.07.2006) suggests that diversity issues can be explored by roleplaying as a part of a virtual exchange program between the members of two culturally different communities.

Online fantasy role-playing communities present interestingly complex cases in the sense that they are built upon three different dimensions: (1) the real world, (2) a fantasy or 'projective' world, (3) an online, virtual world, which blend with each other in an interesting manner. Even the term "virtual" means the intellectual, fantasy and the online, computerized aspects together. While both the fantasy and virtual world share the common denominator of non-reality, the online dimension provides the environment that makes this mixing of reality and non-reality possible in an unprecedented way. The reflective interaction between the fantasy and reality provides various types of knowledge transfer in the form of identity and experience that occur between the different physical/real, online/virtual and intellectual/mental dimensions (Medeni and Medeni, 2005).

In general, online fantasy role-playing communities present interestingly complex cases in the sense that they are build upon three different dimensions: the real world, a fantasy or 'projective' world, and an online, virtual world, which blend with each other in an interesting manner. Even the term "virtual" comprises the mental, fantasy and the online, computerized aspects together within its terms of digital, artificial and fictitious. While both the fantasy and virtual world share the common denominator of nonreality, the online dimension provides the environment that makes this mixing of reality and non-reality possible in an unprecedented way, which can become so complex that sometimes the boundary between the virtual fantasy and real worlds becomes indistinct. For such online role-playing communities and virtual fantasy environments, for instance, Jovchelovitch's (2007) provides a general framework of knowledge in context, underlining representation as potential space and social creation.

For the purposes of education at schools and development at work places, online fantasy role-playing communities such as Second Life can be given as examples of tools for computer supported collaborative learning (Dourish and Bellotti, 1992) or cooperative work (Koschmann, 1996), as well as adaptive training systems (Raybourn 2007). Online learning is often supported by technologies that provide task-oriented groups such as classes or professional development teams with their own workspaces for interaction (Suthers, Chu, Joseph 2008). Nevertheless; collaborative learning at schools and cooperative work at work places are related, have partly shared roots, but are different in terms of processes, methods and rewards (Hamalainen, 2006). Specific for education, also, until recent time, it is still noted that while there is widespread recognition of the advantages for elementary and secondary education, there is little evidence in higher education (Ebner and Holzinger 2006).

As a representational format, ICT operates as a sensual masking. The character chosen by a role player can be seen as a mask acting as a metaphor for the person. 
Just as the transfer of knowledge from ICT to production (the CAD and 3D modeling systems) materially affects our architectural world, the roles played in virtual worlds can have an important practical impact on our personal identities and personalities. Besides, the two terms - object and metaphor - inform each other. Having been involved in fantasy role-playing, immersed in virtual narratives, for a player it becomes difficult to think of fantasy, mystic creatures such as elves or wizards now without seeing them as a particular form of computer user (Wiszniewski and Coyne, 2002). In fact, the self-images that people create in virtual communities show that there is a reflection of the person in the fantasy character that is created and played. These reflections may be physical, but may also be aspects of a person's personality. Some players almost self-consciously construct a persona that is completely opposite to the one they project in real life. The virtual environment provides a filter and can be used as a way to express a different side of personalities, escape the social constraints of real life, or experiment and find out what kind of person one wants to be in real-life (Twist, 2004). Furthermore, in the fantasy role-playing games, personal rivalries can also be masked as role rivalries, for example, when determining who will be leading others (Fine 2002).

Role-playing, taking part in the creative writing of a story, could be an important tool for individual and collective reflection and learning. Learners can benefit from virtual communities in which they can generate virtual characters, or avatars that can 'walk and talk' to develop their personal characteristics and interpersonal skills for real life, synchronously or asynchronously (Takahashia et. al., 2005). It does not matter whether these virtual communities are specifically designed for role-playing only, or for other purposes like learning or social networking, in which role-playing could be used purposefully as a means for personal development or social interaction. For instance, an alumni network that incorporates role-playing can be established, where graduates of the education program can continue to move on their life lines, being able to not only simulate 'good old days' but also include new characters and chapters in their life stories. To sum up, Mitchell and Savill-Smith (2004, p. 53) recommends that designers who create virtual fantasy role-playing games or incorporate role-playing aspects in virtual communities should not only provide members/players with opportunities for assuming different 'virtual' and 'projective' identities, but also seek to promote an appreciation of diversity in the community by encouraging members/players' "reflection on the new identities they have assumed and on other identities, real, virtual and projective," which they or other members have already formed.

In this section we have presented the main aspects of our conceptual framework. To sum up our main argument, we think that asynchronous communication tools for storytelling and role-playing can be fruitful for individual and collective reflections, which provide an invaluable link between learning and practice, tacit and explicit knowledge, the conceptual and the actual, or the virtual and the real. Next, we will benefit from this conceptualization to discuss the findings of our research in online fantasy role-playing games. 


\section{Learning and Reflection in an Online Fantasy Role-playing Gaming Community}

In the previous section, we have discussed a framework of reflection and learning through asynchronous communication tools in online fantasy role-playing gaming. Within this framework that we have discussed above, now we would like to investigate more about the reflective learning dynamics within the online role-playing communities. We want to present the insights of experienced players that we have got the chance to learn through e-research methods such as Internet interviews, and our own observations that are an outcome of our participation in the online gaming community.

When people play in online games, they also behave or act in social settings that can contribute to their learning and development. For instance; in the virtual gaming communities, the players could be less afraid of the consequences of their behaviors and actions, while feeling fun from their participation in these online games - and for these players emotions as such fear and fun could, purposefully or incidentally, contribute to learning by experience and experiment. Besides, in these role-playing communities, within the characters and stories that the players create, reflections from the lives or personalities of the creators could be found or traced. Even then what is experienced through this virtual role-playing could also be reflected back to the real lives for the betterment of the existing situation or specific conditions/concerns.

Here, reflection could be simply summarized as the link between conceptual or imaginary and actual or real, and deserves to be emphasized as an important concept for the development of learning communities, pedagogies, and (interface) technologies. As a result of our previous research and experience in fantasy role-playing games, we have distinguished three types/levels (intra-personal, personal, inter-personal) of reflection and learning, which are interrelated with and complement each other, although too important to combine into one general discussion of reflective learning. $A$ selected collection of interesting and insightful responses to our questions about these three kinds of reflective learning can be found in the subsections below.

\section{Intrapersonal reflection and learning}

To investigate the intra-personal learning and reflection we have asked the respondents what they think about the following comment:

As a player, you discover something special about your own self that you have not been aware of before. Furthermore, in the game, you can decide to experiment on your game character in order to become or not to become something about your real character. ${ }^{3}$ You may benefit from the experience of and experiment with your characters and role-playing in games to improve your personality characteristics, your general attitude to life or to quit some disliked trait or habit.

Below is a good account of what the players think of this kind reflection and learning. The respondent is I. D. from Belgium, and their comments here contain no 
change or editing except that some specific information about their identity is omitted or replaced by more general terms.

\begin{abstract}
I have to agree that by playing Online Role-playing I HAVE discovered more about myself as well. I turns out that gradually I am finding more about myself in my online character. Questions have been going true [sic] my mind about the difference between myself and my character. I play a paranoid, highly suspicious character. Questions came to my mind when I was reading your mail about why I actually chose to become this character. Turns out, in real life I tend to distrust situations also. I will never trust sales talks, I will always doubt when so called beneficiaries are going to "help" the company with some sort of loan or by buying shares. "Hostile take over" would be the first thing that pops to my mind. So in fact, I am most likely as paranoid as my online character really is. Now comments by our game master who has asked me why my character is always so paranoid and the fact that apparently it has also annoyed some players, made me realize that maybe in real life this annoys people as well! I never thought of it this way. In the gaming community it is very easy to comment on someone's character as it is only a "Role-playing" character. But apparently there's more behind it that I thought. So yes, you can say that playing Online Role-playing games has taught me something about myself. And then we're only talking about the relationship one has with his/her's online character".
\end{abstract}

These comments highlight an intra-personal reflection, which is, more or less experienced by many gamers in the world at the moment. As Powasek (2001) and Twist (2004) point out, tens of millions of people worldwide interact in online games and that number is growing. Role-playing games have developed entire virtual worlds and communities with complex social elements and interactions aside from the aspect of gaming. This can become so complex that sometimes the boundary between the virtual fantasy and real worlds becomes indistinct. The more technological or administrative control players have over their fantasy characters, the more likely that the character will be some sort of reflection or refraction of the real person, $a$ creation of a new reality in a mirror world, or in a funhouse trick mirror (Fader, 1998). As commented by Thinkanalogous (2004a, accessed 13.07.2006) on Internet, your character is a reflection of yourself, and everyone else's character is also a reflection of their own selves. Besides, your experience of everyone else's character as well as everyone else is also a reflection of yourself. Furthermore, reflection upon how your game character and experience is a part or reflection of you can be a very effective tool for self growth. In exploring the gaming interactions of the gaming group, and trying to change the patterns found to be unproductive or unhealthy, players can gain new productive and healthy patterns in their real life (Thinkanalogous, 2004a, 2004b, accessed 13.07.2006). However, realizing this potential for self-growth "depends to a great deal on how hard the player involves him or herself" and "the degree to which he or she does it consciously (Al)", some players become aware of this potential and some others do not.

Even if conscious use of reflection could depend on the personality, there is also the possibility of observing reflections of a more unconscious kind, as also another 
player comments: "One WILL role-play any unperceived social flaws that she does not realize she exhibits. Essentially, what l'm saying is that if a person has a social flaw, it WILL come out in their role-playing. If a person habitually lies, he WILL cheat on dice rolls. If a person tends to bottle up everything from work and release it on his family, he probably will do so in character from time to time. etc. I've seen it happen many times in my games." He concludes, "one must be free enough to spit out ideas that are not fully formed without fear of reprisal. This is a setting where social flaws will come out and the more so as the people get to know each other and trust builds."

\section{Personal reflection and learning}

Your character can experience the use of a personal ability or skill (such as cooking, bluffing, gathering information, balancing...) in the ongoing story, or imagines and writes (plays) the role about a specific action (such as standing to a freezing water that your character is in, making an artistic or physical performance, convincing someone with your argument against his/her argument...) which then receives feedback from the fellow players or game master. This could help you improve the conceptualization and comprehension of what your character has done. Then one day you realize that you perform such action and skills much better in your real life...

This is what we have asked our respondents to comment on, hoping that we would get some useful insights about this specific type of reflective learning. According to this personal reflection, for instance, as in simulations, one could virtually try the accomplishment of a task, which could have a risk of physical injury in real life, and later on reflect his/her learning from this trial into actual practice. Our expectations have been grounded upon the "language action perspective, as articulated by Flores, Graves, Hartfield, and Winograd (1988, p.156), which translates the observation that language is a means for taking action into a novel basis for designing technological support for human action: 'The orientation within which we go about design is one that allows human beings to observe their producing and acting in a world linguistically, to design their actions together, and to recognize and respond to breakdowns.' " (Aakhus, 2001, p. 64) Nevertheless, the responses have not been very much supportive of this type of reflection and evidence found for personal reflection has remained mostly for the internalization of knowledge acquired from real life, rather than from virtual play.

"._. Nope, nope, sorry, Tunc. I can't buy that...you can play a wizard until you are blue in the face, but it won't make you a better real-life spell caster! Even more mundane things, do not, I think, carry over. Does having lots of ranks in Craft Weapons make you a better smith? No way. The only exception I would allow might be social skills (Cayzle)".

". I I think that in a way, you have this backwards. Personally, I don't find much meaning in the meta-experiences produced by rolling for skills and such. Rather, I think what is gained, is not so much a meta-experience that one can apply to real life when the real experience comes along, but a vehicle in which one can take experiences that one already has and, through the process of gaming, relive them to a certain extent. This forces the player to make the experience 
more concrete for him or herself in many ways that could be enhancing from a learning standpoint, or even therapeutic... Gaming, especially in a format like this, could be used to work through personal trauma by gaming it through a character. I know [th]at I, personally, have created a character modeled in part after my ex-wife. In many ways, it's allowed me to direct my attentions towards many feelings that l've had surrounding our devoice [sic]. Could be other things as well, fear of heights, fear of the dark. Anything.... However, I don't think a player can get a sense of how something happens in a physical situation unless they've had a similar experience themselves (identity not disclosed)".

Thus, with the exception of social or language skills, this type of reflective learning is mainly related to the personal internalization of specific skills or knowledge as a deliberate thinking on past experience. And the exception of social skill becomes the general consensus when we consider reflection at a more interpersonal level, which we will discuss next.

\section{Interpersonal reflection and learning}

As a part of your social interaction with your fellow characters, game masters, or fellow players you come to know better how to develop your relations, work as a team, lead, be led, plan, take action, make friends, find lovers etc. Compared to those above, perhaps these are improvements in more generic skills and abilities.

As far as the responses to this comment are concerned, it is generally agreed that social interactions in the gaming communities can help players develop some important transferable interpersonal skills. For instance our respondents have become better at skills related with communicating and dealing with others or strangers, and they have been able to transfer these skills gained through virtual experience to real life. Other responses are as the following:

". I I see the distinct possibility for this. Not only from a personal standpoint, that is to say, the player interacting with other players, and the game master, team building and such. But it also allows the player to explore characters/ personalities other than his or her own. ...Whereas the physical sensations may not be available to the player, the social context is very real. Reactions from other characters will be as real as the other players allow. (Al)"

". I found how people think of me and how I react to that...I have also learned how to react to people. I am jumpy when others blame me for something! Both in game and in real life. I basically want people to like me. The online community does give one the chance to meet all sorts of people, and you get to see how other[s] react to your own person - and this from people all over the world! I now know that the same word can be more serious in one nation than in the other. Apparently people react differently all over the World... And more importantly, in my profession I often have to guide brainstorms and meetings - somehow I feel things have improved. I don't know exactly when this happened, but I am able to react better during though meetings, I seem to be able to explain why I am in favor or against without actually attacking the others. 
Basically there's much more behind Role-Playing than one thinks. (I.D.)"

\begin{abstract}
Well, yes, I agree with that. Role-playing games are social games, and include a wide range of social behaviors, from cooperative planning to improvisational storytelling and acting. I would not call these "generic," per say, but just the opposite -- narrow and limited to a social band of skills... Like I said, I certainly feel that my own social skills have improved. I was a shy introvert in high school, but I have been able to work as a teacher, a telemarketer, and a decision maker and manager in part, I think, due to the social skills that gaming helped me develop. I think that the Wold, in particular, being a written game, has improved my writing as well as -- and this is a pretty specific skill -- my ability to resolve conflicts and engage people emotionally through written electronic media (Cayzle)".
\end{abstract}

Externalizing personal knowledge and constructing collective knowledge through reflective interactions with other players is also another important gain. Our research on the virtual facilities of Wold for discussing the game rules or item developments, as a participating member, also supports this finding (Medeni, 2005). These specific boards, Rules Center and Black Genie Center enable members to discuss game rules, or develop new items to be used by characters in the scenarios. For interested members, these boards function effectively for personal and collective reflection. Members are given the space and time to externalize their thoughts and ideas, discuss them with each other, take time to internalize and develop their thinking and ideas that can result in interesting outcomes. As Markel (2001) suggests that this particular use of the discussion forum, to negotiate and construct knowledge, is an example of using the technology as a cognitive tool to stimulate cognitive learning strategies and critical thinking...Participants draw upon their own experiences and interpretations and share these with the group discussion... This involves the processes of reflection and the construction and re-construction of domains of knowledge. The resulting kind of learning from these processes is a negotiated interpretation of knowledge, deeper, more long lasting and refined.

\title{
Discussions and Conclusion
}

In this paper, we have tried to provide a stimulating account of learning and reflection that occurs at intra-personal, personal and inter-personal levels in online fantasy roleplaying games, benefiting from the academic discussions and practical insights. We believe the findings from our research in Wold about storytelling and fantasy role-playing for reflection and learning through asynchronous communication would have more general implications for other digital (role-playing) games and (virtual) communities of practice to be used for learning and development. Some limitations also come together with these implications. We conclude our paper by briefly discussing these implications and limitations in order to attract the attention of researchers and practitioners to further investigation. 
Firstly, as one of our respondents comments, the idea that the experiences people take from virtual gaming communities can be applied to real life:

\begin{abstract}
". Apply to any virtual community with a consistent membership over time. Another example of such a community might be a Listserv. In such cases you take on an identity that is yourself, but a self that can be different than your physical self in that, as you say, you are less afraid of the consequences of your behaviors and actions. You can participate in violent discussions. Throw insults that you would not in daily life. And, from the result of that experience, you can take away strategies for dealing with the art of the Argument. The same goes for other more possibly constructive acts. Helping behavior, the Art of Explanation, social etiquette, and many others. (Al)"
\end{abstract}

Specifically for the asynchronous communication aspect, Steeples argues (1998) that text-based computer-mediated communication is well suited for academic discourse, for example, for abstracted discussions about theoretical knowledge. However, it fits less well in vocational educational contexts, "especially where we wish to encourage professionals to share tacit knowledge about working practices and procedural skills. Sharing knowledge that is tacit and embedded in practice in textual messages has proven to be extremely difficult. As a direct and innovative response to the needs for sharing and collaboratively improving vocationally-oriented knowledge", use of asynchronous multimedia conferencing has been proposed (Steeples, 1998, accessed 15.09.2005):

\begin{abstract}
"._Clearly... the asynchronous medium affords flexibility over time and space, as well as opportunities for reflection. Using multimedia affords a more direct experience: practitioners can demonstrate and show, rather than only being able to describe and explain. Multimedia affords a richer and more naturalistic form of communication for articulating about tacit knowledge. The purpose of making multimedia representations is to share and discuss them with other colleagues. The conferencing environment supports this sharing and discussion among members of distributed practitioner communities. The environment enables professional development among peers and is a resource that can especially be made available to newer members of the professional community".
\end{abstract}

During asynchronous communication processes, reflection can be facilitated due to the text-based format and the asynchronous character. Specifically, the possibility of expressing oneself actively in writing anytime without competing is a potent mode of learning (Bernath and Rubin 1999, Bernath and Hülsmann, accessed 15.07.2006). Writing for the purposes of role-playing and storytelling adds another important dimension to the benefit of online text-based communication for personal development. Moreover, on-going collaborative creative writing in online stories, such as the ones in Wold, is a unique learning experience of its own.

The voices and arguments that have been provided in this paper reflect different perspectives. For instance, responses about the impact of storytelling and role-playing on learning and reflection could be different for "a creative writing perspective" compared to "a strict gaming perspective". However, as a common ground, all the respondents have had, more or less, a game mastering experience in addition to playing experience 
in the games. And, we believe that this game mastering experience provides a richer, deeper and better-capturing perspective for research.

Finally; whileinvestigating thelearningand developmentthatoccursnaturallythrough asynchronous communication tools in informal virtual communities (or in any shared context for relationship-building and knowledge creation), reflection (and refraction, or creative and critical reflection) can be an effective method for experimentation (testing and evaluating different personal characteristics), externalization (discussing with others for problem solving) and internalization (deliberate thinking on experience). We believe individual methods for different reflections can be systematized and integrated into a reflection methodology for learning and practice.

\section{Acknowledgements}

The authors would like to thank to the players of Woldian games for their insightful and interesting comments, and to the Editors and Reviewers for their constructive and helpful suggestions.

\section{Endnotes}

1. See also Kaye, 1992; McConnell, 1994; Koschmann, 1996

2. Page number is not cited in the original source

3. During the games, for instance, a player can have the chance to express some personality traits that are suppressed in real life. Or, different players can try out different characteristics of life that they have not yet experienced in their actual lives. As a result of this experimental experience, some habits or patterns of their own characters or lives that they feel dissatisfied or uncomfortable with could be changed or replaced by the ones that they would be happier about. Besides, it is also likely that rather than the habits or patterns, the feelings about these could be the ones that are changed.

\section{References}

Aakhus, M. (2001). Designing web-based interactional tools to support learning from experience, paper presented at the Sixth International Workshop on the Language-Action Perspective on Communication Modelling (LAP 2001). Available online at: http://www-i5.informatik.rwthaachen.de/conf/lap2001/papers/paper8.pdf (accessed 15.07.2006)

Anderson, T. and Kanuka, H. (2003). E-research: Methods, strategies, and issues. Boston: Pearson Education.

Ateşsoy Y. (n.d.). Yaran. Available online at: http://www.cankiri.gov.tr/ana/kultur/yaran.htm (accessed 15.07.2006) 
Barrett H. (2004a). The eportfolio as a story of deep learning: Digital storytelling as a part of a reflective portfolio, paper presented at the e-Portfolio Conference: Reflection Is Not a Mirror, It's a Lens Available online at: http://electronicportfolios.org/portfolios/ReflectionUBC.pdf (accessed 15.07.2006)

Barrett H. (2004b). Electronic portfolios as digital stories of deep learning: emerging digital tools to support reflection in learner-centered portfolios. Available online at: http://electronicportfolios. com/digistory/epstory.html (accessed 15.07.2006)

Bernath, U. and Hülsmann, T. (2006). Asynchronous discussions in virtual seminars: might they work? Available online at: http://66.102.7.104/search?q=cache:fGmtE2kSznwJ:www.unioldenburg.de/zef/literat/eden0203.pdf (accessed 15.07.2006)

Bernath, U. and Rubin, E. (1999). An international virtual seminar for university faculty and administrators: Professional development in distance education, paper presented at the 19th ICDEWorld Conference in Vienna. Available online at: http://www.uni-oldenburg.de/ zef/literat/vienna2.htm (accessed 15.07.2006).

Bodemer, D. and Sholvien, A. (2008). Support for Collaborative Multimedia Learning:Considering the Individual and the Group. ICCE 2008 Proceedings, pp.245-252.

Collison, C. and Parcell, G. (2004). Learning to fly: Practical knowledge management from leading and learning organizations. Chichester: Capstone.

Dourish, P. and Bellotti, V. (1992). Awareness and Coordination in Shared Workspaces. In J. Turner and R. Kraut (Eds.) CSCW 92 - Sharing Perspectives. Proceedings of the Conference on Computer-Supported Cooperative Work (pp. 107-114). Toronto: ACM/SIGOIS.

Ebner, M. and Holzinger, A. (2006). Successful implementation of user-centered game based learning in higher education: An example from civil engineering. Computers and Education Elsevier.

Elearnspace. (2005). Asynchronous Available online at: http://www.elearnspace.org/doing/ asynchronous.htm (accessed 15.07.2006).

Fader, S. (1998). Role-playing games Available online at: http://www.nycgoth.com/more/rpgs (accessed 15.07.2006).

Filipczak, B. (1997). Training gets doomed, Training, August, 24-31.

Fine, G. A. (2002). Shared fantasy: Role playing games as social worlds. Chicago: University of Chicago Press.

Flores, F., Graves, M., Hartfield, B. and Winograd, T. (1988). Computer systems and the design of organizational interaction. ACM Transactions on Office Information Systems, 6(2), 153172.

Galarneau, L. (2004). PhD proposal: Spontaneous communities of learning. Available online at: http://www.oddwater.com/relevancy/index.php?p=81 (accessed 15.09.2005).

Gee, J. P. (2003). What video games have to teach us about learning and literacy. New York: Palgrave Macmillan. 
Goldberg, M. (n.d.). Synchronous vs. asynchronous: Some thoughts. Available online at: http://www. webct.com/OTL/NiewContent?contentID=2339346 (accessed 15.07.2006).

Griffiths, M. D. and Davies, M. N. O. (2002). Research note-excessive online computer gaming: implications for education. Journal of Computer Assisted Learning, 18(3), 379-380.

Hamalainen, R. (2006). Designing and evaluating collaboration in a virtual game environment for vocational learning. Computers and Education, 50(1), 98-109.

Joinson, N. A. (2003). Understanding the psychology of Internet behaviour: Virtual worlds, real lives. New York: Palgrave Macmillan.

Jovchelovitch, S. (2007). Knowledge in context: Representations, community and culture. New York: Routledge.

Karatekin Yaren Kültürü (n.d). Available online at: http://www.karatekin.net/yaren/ (accessed 15.07.2006).

Kaye, A. (1992). Collaborative learning through computer conferencing: the Najaden papers. Berlin: Springer-Verlag.

Koschmann, T. (1996). CSCL: theory and practice of an emerging paradigm. Mahwah, NJ: Lawrence Erlbaum.

Koschmann, T. (1996). CSCL: Theory and practice of an emerging paradigm. Mahwah, NJ: LEA.

Lacan, J. (1977). Ecrits. New York: Norton.

Lave, J. and Wenger, E. (1991). Situated learning: Legitimate peripheral participation. Cambridge: Cambridge University Press.

Lee, K. M. (2000). MUD and self efficacy. Educational Media International, 37(3), 177-183.

Lortz, S. L. (1979). Role-playing. Different Worlds, 1,36-41.

Lue, K. (2005). Building social capital on college campuses: Outside the classroom and online, (CVC Professional Development Center). Available online at: http://pdc.cvc.edu/common/article. asp?entry=1\&idx=3708 (accessed 15.07.2006).

Markel, S. (2001). Technology and education online discussion forums: It's in the response' Online Journal of Distance Learning Administration, 4(2). Available online at: http://www.westga.edu/ distance/ ojdla/summer42/markel42.html (accessed 15.07.2006).

McConnell, D. (1994). Implementing computer supported cooperative learning. London: Kogan Page.

Medeni, T. (2004). Reflective management learning practice model, presented at the BAI 2004 International Workshop on Business and Information, Taiwan, 26-27 March 2004.

Medeni, T. and Medeni T. İ. (2005). Virtual role-playing communities, "Wold" and World. E. Coakes and S. Clarke (Eds.). In Encyclopedia of communities of practice in information and knowledge management (pp.580-582). Hershey: Idea Group. 
Medeni, T. (2001). Reflections on IMPM reflective mindset module. Unpublished Dissertation presented for MA in Management and Organizational Learning, Lancaster University.

Medeni, T. (2005). The living tradition of "Yaren Talks" as an indigenous community of practice in today's knowledge society. E. Coakes and S. Clarke (Eds.). In Encyclopedia of communities of practice in information and knowledge management (pp.353-356). Hershey: Idea Group.

Medeni, T. (2006). International Masters Program in Practicing Management (IMPM): Pedagogy of experienced reflection and phenomenon of refraction in management learning. Wankel, C. and DeFillippi, R. (Eds.). In New visions of graduate management education (pp.125184). Charlotte, NC: Information Age.

Medeni (ve başkl). (2008). Learning reflection and creativity in online game communities. G. D. Putnik and M. M. Cunha (Eds.). In Encyclopedia of Networks and Virtual Organizations VolII. Hershey, New York: Information Science Reference.

Mintzberg, H., (2004). Managers not MBAs: A hard look at the soft practice of managing and management development. San Francisco: Berrett-Koehler Publishers.

Mitchell, A. and Savill-Smith, C. (2004). The use of computer and video games for learning: A review of the literature. London: Learning and Skills Development Agency. Available online at: http://www.lsda.org.uk/files/PDF/1529.pdf (accessed 15.07.2006).

Murray, J. (2004). From game-story to cyberdrama. Available online at: http://www. electronicbookreview.com/v3/servlet/ebr?essay_id=murray\&command=view_essay (accessed 27.09.2005).

Nonaka, I. and Teece, D. J. (2001). Managing industrial knowledge: Creation, transfer and utilization. London: Sage.

Nonaka, I. and Takeuchi, H. (1995). The knowledge creating company: How Japanese companies create the dynamics of innovation. New York: Oxford University Press.

Powazek, D. M. (2001). Design for community: The art of connecting real people in virtual places. New Riders Press.

Raybourn, E. M. (2007). Applying simulation experience design methods to creating serious game-based adaptive training systems. Interaction with Computers, 19(2), 206-214.

Schön, D. (1983). The reflective practitioner: How professionals think in action. San Francisco: Jossey-Bass.

Schön, D. (1988). Coaching reflective teaching. P. Grimmett and G. Erickson (Eds.). In Reflection in Teacher Education (pp.19-29). New York: Teachers College Press.

Shih, J. L. and Su, H. Y. (2008). Analyzing children's cognitive activities in digital problem-solving learning games "William Adventure": An in-depth case study. In ICCE 2008 Proceedings (pp. 651-658). 
Steeples, C. (1998). Educational issues in collaborative learning. Available online at: http://www. law.warwick.ac.uk/seminars/98-2-cs.html (accessed 15.09.2005).

Steinkuehler, C. A. (2005). Cognition and learning in massively multiplayer online games: A critical approach. Available online at: https://mywebspace.wisc.edu/steinkuehler/web/papers/ Steinkuehler_ch4.pdf (accessed 15.09.2005).

Suthers, D., Chu, K. H. and Joseph, S. (2008). Socio-technical capital in online learning: A preliminary investigation. In ICCE 2008 Proceedings (pp. 857-864).

Takahashia, T., Bartneck, C., Katagiria, Y. and. Araic, N. H. (2005). TelMeA-Expressive avatars in asynchronous communications. International Journal Human-Computer Studies, 62(2), 193-209. Available online at: http://www.bartneck.de/work/takahashiBartnecklJHCS.pdf (accessed 15.07.2006).

Techsoup.(2005). Asynchronous communication for online learning and collaboration. Available online at: http://www.techsoup.org/fb/index.cfm?forum=2008\&fuseaction=forums. showSingleTopic\&id=58245 (accessed 15.07.2006).

Thinkanalogous. (2004a). Gaming group growth: Character interactions. Available online at: http://www.gamegrene.com/node/371 (accessed 15.07.2006).

Thinkanalogous. (2004b). Role playing for self improvement. Available online at: http://www. gamegrene.com/node/339 (accessed 15.07.2006).

Totty, M. (2005). Better training through gaming: Making work more like play The Wall Street Journal Online. Available online at: http://www.careerjournal.com/hrcenter/articles/20050428-totty. html?cjcontent=mail. (accessed 15.07.2006).

Tsikalas, K. E. (2001). When the sims get real: An analysis of how digital playspaces promote learning in low-income, diverse communities. Available online at: http://66.102.9.104/sea rch?q=cache:3q76a0FMqwYJ:playspace.concord.org/Documents/Learning\%2520from\% 2520The\%2520SIMS.pdf+When+The+Sims+Get+Real\&hl=en\&ct=clnk\&cd=5 (accessed 14.07.2006).

Twist, J. (2004). Virtual gamers reveal themselves BBC News. Available online at: http://news. bbc.co.uk/1/hi/technology/3683260.stm (accessed 15.07.2006).

Umphrey, M. L. (2005) ALERT: Learning as narrative process. Available online at: http://www. edheritage.org/tools/alert.htm. (accessed 15.07.2006).

Weick, K. E., (1995). Sensemaking in organizations. London: Sage.

Wiszniewski, D. and Coyne, R. (2002). Mask and identity: The hermeneustics of self-construction in the information age. K. Ann Renninger (Ed.). In Building virtual communities: Learning and change in cyberspace (learning in doing: social, cognitive and computational perspectives) (pp.191-214). Cambridge: Cambridge University Press. 